\title{
A common congenital immunodeficiency predisposing to infection and atopy in infancy
}

\author{
V F RICHARDSON, V F LARCHER, AND J F PRICE \\ Department of Child Health, King's College Hospital Medical School, London
}

SUMmARY Twenty six infants with a congenital immunodeficiency, characterised by failure of their sera to opsonise heat killed bakers' yeast for phagocytosis by normal polymorphonuclear leucocytes, were studied during infancy to determine the frequency of infection and development of atopy. They were compared with controls, matched prospectively for birth date, sex, parental smoking, and atopy and in whom feeding patterns were similar. In 18 of 26 infants the serum defect persisted at age one year. The incidence of infection and atopy, was appreciably greater in the study group than in controls. The 8 children in whom the defect was transient had a similar incidence of infection but a higher incidence of atopy than controls. Eight of 26 mothers and four of 9 fathers tested also had the serum defect, suggesting a strong genetic component. We support the hypothesis that immunodeficiency predisposes to infection and atopy, and that transient immunodeficiency predisposes to atopy.

Failure of serum to opsonise heat killed bakers' yeast for phagocytosis by normal polymorphonuclear neutrophil leucocytes was first described in association with severe recurrent, often fatal, infection in infancy. ${ }^{1}$ The defect occurs in $5 \%$ of the normal population ${ }^{2} 3$ but is more frequent in atopic children ${ }^{4}$ and those with recurrent lower respiratory tract infection. ${ }^{5}$ Although it is hypothesised that these defects precede the onset of illness, there have been no formal prospective studies to corroborate this.

In a previous study we identified a population of infants who possessed the serum defect at birth. ${ }^{6}$ The aim of the present study was to compare, during the first year of life, the incidence of serious infection and atopy in this previously identified group of infants with matched controls. Since a higher than expected proportion of infants studied $(10 \%)$ possessed the serum defect at birth we wished to see whether in some the defect was transient, and if so whether it was also related to the development of infection and atopy.

\section{patients and methods}

Sera from 30 of a group of 303 healthy, term infants born between August 1980 and January 1981 were found to be defective in yeast opsonisation activity. These infants were matched with others from the group for date of birth (within 2 weeks), sex, parental atopy (defined by positive prick tests to common allergens) ${ }^{6}$, parental smoking, and social class.

Four infants with defective yeast opsonisation were lost to follow up. The remaining 26 (12 boys and 14 girls), together with their matched controls, were assessed at one year of age by one of us (VFR), who did not know at the time which infants had the defect. For each infant a history was taken of frequency and type of infection since birth. A mild illness with transient rhinitis and minor cough or feeding difficulty was classified as an upper respiratory tract infection (URTI). A more serious illness with pyrexia, tachypnoea, feeding difficulties, and severe cough was classified as a lower respiratory tract infection (LRTI). In each case of LRTI the general practitioner had made the diagnosis, prescribed antibiotics, and there was improvement within 48 hours. Cases of gastroenteritis were recorded if watery diarrhoea was present for at least 5 days and required medical supervision. Abscesses or paronychia were grouped as 'skin infections'. Otitis media was included only when the diagnosis had been made by the general practitioner and treatment given with antibiotics.

A history was also taken of immediate hypersensitivity reactions after food ingestion. The babies were examined for evidence of eczema, and this was graded as described. ${ }^{7}$ They were skin prick tested ${ }^{8}$ with extracts of house dust, house dust mite, cat fur, 
dog hair, grass poilen, mixed moulds, egg, and cows' milk, together with a control solution (Bencard). A positive reaction in these infants was taken as an immediate wheal of at least $1 \mathrm{~mm}$ and no response to the control solution. ${ }^{9}$ Atopy was considered present if the infant had one or more of the following: (1) grade 2 or 3 eczema; (2) positive prick test; (3) a history of an immediate hypersensitivity reaction to ingestion of a specific food on repeated occasions. The duration of exclusive breast feeding and the age of first introduction of solids was recorded and each infant was weighed.

Blood was taken and sera stored at $-70^{\circ} \mathrm{C}$ until examined. Yeast opsonisation activity was redetermined using the coulter counter method ${ }^{3}$ in the serum of all infants, their mothers, and some of the fathers.

\section{Results}

Fifteen infants in each group had at least one atopic parent ( 2 infants in the serum defective and 4 in the control group had 2 atopic parents); 14 had parents who smoked (both in 4 infants, the mother only in 2 , and the father only in 8); 10 infants came from social classes 1 and 2, 12 from social class 3 , and 4 from social classes 4 and 5 . There were no appreciable differences in either the duration of exclusive breast feeding or the age of solids introduction between the infants defective at birth and the controls (Figure). There were no notable differences in either birth-

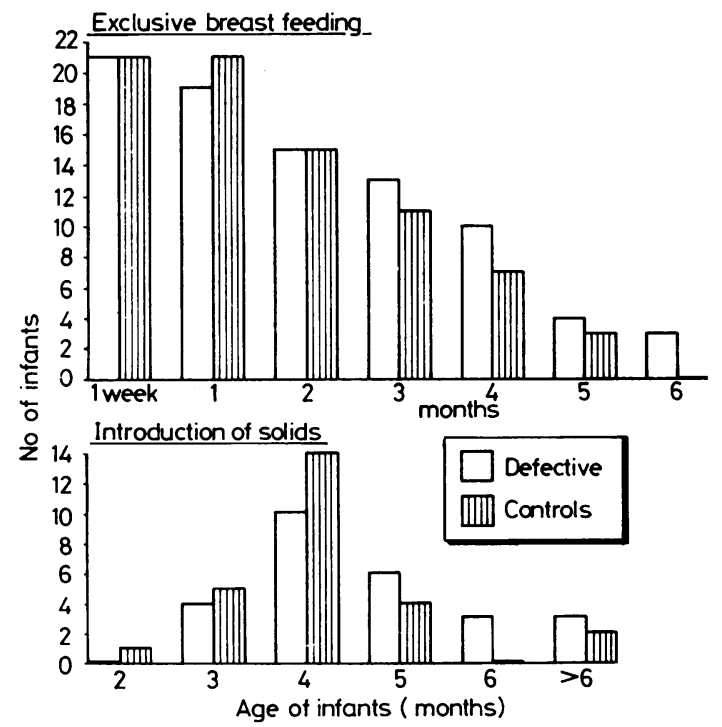

Figure Comparison of feeding methods in the immunodeficient and control infants. weights or weights at age 12 months between the two groups. URTIs occurred with the same frequency in both groups-23 infants in the defective group and 24 in the control group had at least one URTI, and 13 in each group had 3 or more.

Serious infections were significantly more frequent in babies with the serum defect (Table 1). In particular 9 babies in the defective group compared with only 3 in the control group had otitis media $(P=0.097$ Fisher's exact test). Atopy was also more common in infants with the serum defect compared with controls (Table 2). All 8 infants who were atopic and also had one or more serious infections were defective in yeast opsonisation $(P=0.0042$ Fisher's exact test).

Eight infants who were serum defective at birth had normal yeast opsonisation activity at one year. Four of these had one serious infection compared with two of their matched controls (not statistically significant). None had recurrent infections. The frequency of atopy in the transiently defective babies (5 of 8) was greater than in their matched controls

Table 1 Frequency of serious infection in immunodeficient and control infants

\begin{tabular}{|c|c|c|}
\hline & $\begin{array}{l}\text { Immunodeficient } \\
\text { infants }\end{array}$ & $\begin{array}{l}\text { Control } \\
\text { infants }\end{array}$ \\
\hline $\begin{aligned} \text { LRT1 alone: } & 1 \text { occasion } \\
& >1 \text { occasion }\end{aligned}$ & $\begin{array}{l}2 \\
0\end{array}$ & $\begin{array}{l}0 \\
0\end{array}$ \\
\hline \multicolumn{3}{|l|}{ Gastroenteritis alone: } \\
\hline 1 occasion & 4 & 5 \\
\hline$>1$ occasion & 1 & $\mathbf{0}$ \\
\hline \multicolumn{3}{|l|}{ Skin infection alone: } \\
\hline 1 occasion & $\mathbf{0}$ & 0 \\
\hline$>1$ occasion & 1 & 0 \\
\hline \multicolumn{3}{|l|}{ Otitis media alone: } \\
\hline 1 occasion & 3 & 1 \\
\hline$>1$ occasion & 2 & 1 \\
\hline Otitis media + LRT1 & 1 & $\mathbf{0}$ \\
\hline Otitis media + gastroenteritis & 1 & $\mathbf{0}$ \\
\hline Otitis media + skin infection & 1 & 1 \\
\hline $\begin{array}{l}\text { Otitis media + LRT1 }+ \\
\text { gastroenteritis }\end{array}$ & 1 & $\mathbf{0}$ \\
\hline Total & $17^{*}$ & 8 \\
\hline
\end{tabular}

*P=0.025 (Fisher's exact test)

Table 2 Frequency of atopy in the immunodeficient and control infants

\begin{tabular}{lll}
\hline & $\begin{array}{l}\text { Immunodeficient } \\
\text { infants }\end{array}$ & $\begin{array}{l}\text { Control } \\
\text { infants }\end{array}$ \\
\hline $\begin{array}{l}\text { Eczema alone } \\
\text { Positive skin test alone }\end{array}$ & 7 & 2 \\
$\begin{array}{l}\text { Eczema and positive skin test } \\
\text { Immediate hypersensitivity to } \\
\text { banana }\end{array}$ & 1 & 1 \\
$\begin{array}{l}\text { Immediate hypersensitivity to } \\
\text { egg and positive skin test }\end{array}$ & 1 & 1 \\
Total & 1 & 0 \\
\hline $\mathrm{P}=0.0078$ (Fisher's exact test) & & 0 \\
\hline
\end{tabular}


( 2 of 8 ) and significantly greater than in the control group as a whole (4 of 26), $P=0.035$. Eight of 18 children with persistence of the serum defect at one year had multiple serious infections either in the same site or in different sites during infancy, compared with one of 18 controls $(P=0.041)$.

The mothers of 8 infants, 6 with a persistent serum defect and 2 with a transient defect, showed the same abnormality. The incidence of serious infection in infants of affected mothers ( 5 of 8 ) was no different from that in infants of normal mothers (12 of 18). Atopy was not significantly more frequent in infants of affected mothers (6 of 8) than in infants of normal mothers ( 8 of 18), $P=0 \cdot 31$. Four of 9 fathers tested had the serum defect. All four infants of affected fathers (with normal mothers) had one or more serious infection, and three had evidence of atopy.

\section{Discussion}

In this study it has been possible to identify prospectively a group of infants with a specific immunological deficiency and to record the incidence of infection and atopy in comparison with a well matched control group. Previous studies have shown that defective opsonisation of heat killed bakers' yeast is a common immunodeficiency state that occurs five times as frequently in atopic individuals as it does in the normal population. The defect is probably caused by failure of $\mathrm{C}_{3}$ b generated from the alternate pathway of complement, to deposit on yeast cell walls. ${ }^{10}$ These studies do not, however, answer the question of whether the immunodeficiency state precedes the development of atopy, or predisposes to recurrent infection. The hypothesis that atopic symptoms occur because of an inbalance of the normal immune response to foreign antigen, resulting in failure of early recognition of the antigen or failure to neutralise or eradicate it, depends on showing that the immunodeficiency state predates the onset of atopy or infection. It was important in this study to match the controls for other variables that have been associated with development of atopy. Matching for date of birth was included because of seasonal variation in antigen exposure, for example to grass pollen or respiratory syncytial virus, that may be unmatched by different ages of susceptibility. This may be of special relevance if the serum defect examined is transient, as it was in 8 of the infants examined. Matching for sex is also important as boys have a high incidence of infection during the first year of life. Similarly offspring of atopic parents have increased incidence of atopy $(50 \%$ if one parent is affected) ${ }^{11}$, and maternal smoking is also associated with increased incidence of respiratory infections. ${ }^{12}$ It is also possible that environmental variation between social classes influences rates of infection and incidence of atopy. It was possible to match all these parameters prospectively.

We were unable to match serum defective infants and controls prospectively for the duration of exclusive breast feeding or the age at which solids were first introduced, although these factors have both been examined for their association with the development of atopy and infection..$^{13} 14$ There were, however, no important differences between either of these variables when histories were taken at one year. Indeed, those in the defective group had slightly longer periods of exclusive breast feeding and delayed introduction of solids, both of which may offer some protection against development of atopy.

The higher incidence of infection in the group with a persistent defect in yeast opsonisation, when compared with controls, confirms the previously observed association between defective opsonisation and increased incidence of infection. The infections that occurred were not life threatening, in contrast to those described in Miller's original group of infants. ${ }^{3}$ This is not surprising since $5 \%$ of apparently healthy children and adults possess the defect, and the close matching of the 12 month weights and nutritional status in both defective and control groups suggests that the former were basically healthy children. It is possible that the group of infants described by Miller et al. had additional immunological defects that rendered them incapable of withstanding serious infection. Some evidence for this comes from studies on children with protracted diarrhoea and fulminant liver failure, in whom other immunodeficiencies in addition to defective opsonisation were found. ${ }^{1516}$ The type of organism responsible for the infection in these children was not defined, but evidence available suggests that both otitis media and some gastroenteritis may be due to encapsulated (for example pneumococcus or haemophilus) or Gram negative organisms, against which opsonisation seems to be an effective means of host defence.

The diagnosis of atopy was made in as objective a fashion as possible and included only previously observed criteria (positive skin tests and eczema) and an unequivocal history of hypersensitivity to ingested food. Only one infant in whom the latter was the only diagnostic criteria was included, and in this child skin testing to the particular food (banana) was not available. Neither wheezing nor rhinitis were included as symptoms in the diagnosis of atopy, since the former is a subjective phenomenon if examined in retrospect and the latter is also subjective and has many causes, 
Nevertheless, using these limited criteria we were still able to show that infants possessing the opsonisation defect from birth had a higher incidence of atopy than controls. We further observed that infants in whom the defect was transient, possibly as a result of maturational delay of the complement system, had the same increased risk of developing atopy. This important observation suggests that the presence of the defect at a critical period of antigen exposure is sufficient to predispose to atopy. Moreover, if these children were to be examined retrospectively the immunological basis of their disease would be missed. It is therefore possible that a specific, identifiable immunodeficiency, whether permanent or transient, predisposes an individual to develop atopy.

We found a similar frequency of serious infection in infants with affected mothers and infants with normal mothers (who presumably inherited the abnormality from their fathers). This observation must be interpreted with caution as these groups were not matched for other factors that may predispose to infection. It does not support, however, the suggestion that infants with abnormal fathers are protected by transfer of factors across the placenta from their normal mothers. ${ }^{2} 5$

Further follow up of these infants is continuing and should identify in detail the problems encountered by a cohort of children with specific immunodeficiency.

We thank the Smith and Nephew Foundation whose fellowship supported Dr V F Richardson, Mrs Mary Boxall for typing the manuscript, and all the parents for their willing cooperation.

\section{References}

1 Miller ME, Seals J, Kaye R. Levitsky LC. A familial plasma-associated defect of phagocytosis. Lancet 1968; ii $: 60-3$.

2 Soothill JF, Harvey BAM. Defective opsonization. A common immunity deficiency. Arch Dis Child 1976;$51: 91-9$.
${ }^{3}$ Levinsky RJ, Harvey BAM, Paleja S. A rapid objective method for measuring the yeast opsonisation activity of serum. J Immunol Methods 1978;24:251-6.

4 Turner MW, Mowbray JF, Harvey BAM, Brostoff J, Wells RS, Soothill JF. Defective yeast opsonization and $\mathrm{c}_{2}$ deficiency in atopic patients. Clin Exp Immunol 1978;34:253-9.

5 Soothill JF, Harvey BAM. A defect of the alternative pathway of complement. Clin Exp Immunol 1977;27:30-3.

6 Richardson VF, Larcher VF, Price JF. Yeast opsonisation in newborn infants and its relationship to parental atopy. Clin Exp Immunol 1982;48:411-6.

7 Matthew DJ, Taylor B, Norman AP, Turner MW, Soothill JF. Prevention of eczema. Lancet 1977;i:321-4.

${ }^{8}$ Godfrey RC, Griffiths M. The prevalence of immediate positive skin tests to Dermatophagoides pteronyssinus and grass pollen in school children. Clin Allergy 1976;6:79-84.

9 Cogswell JJ, Halliday DF, Alexander JR. Respiratory infections in the first year of life in children at risk of developing atopy. Br Med J 1982;284:1011-3.

10 Turner MW, Mowbray JF, Roberton DR. A study of $\mathrm{C}_{3} \mathrm{~b}$ deposition on yeast surfaces by sera of known opsonic potential. Clin Exp Immunol 1981 ;46:412-9.

11 Soothill JF, Stokes CR, Turner MW, Norman AP, Taylor B. Predisposing factors and the development of reagenic allergy in infancy. Clin Allergy 1976;6:305-19.

12 Ferguson DM, Horwood LJ, Shannon FT. Parental smoking and respiratory illness in infancy. Arch Dis Child 1980;55:358-62.

13 Chandra RK. Prospective studies of the effects of breast feeding on incidence of infection and allergy Acta Paediatr Scand 1979;68:691-4.

14 Kramer MS, Moroz B. Do breast-feeding and delayed introduction of solid foods protect against subsequent atopic eczema? J Pediatr $1981 ; 98$ :546-50.

15 Candy DCA, Larcher VF, Tripp JH, Harries JT. Harvey BAM, Soothill JF. Defective yeast opsonisation in children with chronic diarrhceac states. Arch Dis Child 1980;55:189-93.

16 Larcher VF, Wyke RJ, Mowat AP, Williams R. Bacterial and fungal infection in children with fulminant hepatic failure: the possible role of opsonisation and complement deficiency. Gut 1982;23:1037-43.

Correspondence to Dr V F Richardson, Department of Child Health, King's College Hospital Medical School, London SE5 8RX.

Received 25 April 1983 